\title{
Access and use of financial markets for basic education expenses
}

\section{Acceso y uso de los mercados financieros para el pago de los gastos de la educación básica}

\author{
Kristiano Raccanello ${ }^{\mathrm{a}, *}$, Laura Elena Carrillo Cubillas ${ }^{\mathrm{b}}$, \\ Mariana Guzmán Yerena ${ }^{c}$ \\ ${ }^{a}$ El Colegio de Tlaxcala A.C., Mexico \\ ${ }^{\mathrm{b}}$ Galilei A.C., Puebla, Mexico \\ ${ }^{c}$ Deloitte, Mexico City, Mexico
}

Received 5 May 2015; accepted 17 March 2016

Available online 31 May 2017

\begin{abstract}
As a result of the financial crisis of 2008, the macroeconomic adjustment has affected Mexican homes through greater unemployment and a drop in purchasing power. Moreover, families had to keep financing education costs, sometimes going into debt in the formal or informal financial market. The hypothesis of this article proposes that the access and use of formal and informal financial products makes it possible to reduce financial problems associated to education expenses at the basic education levels. The probit model is estimated with a sample comprised of four hundred homes in the municipality of San Pedro Cholula (state of Puebla). The results indicate that a worsening in the work conditions and the loss of employment are associated to a greater probability of facing financial difficulties. Likewise, the access to the formal financial market allows reducing the probability of facing these difficulties, whereas for the informal market the results are a function of the characteristics of each financial intermediary.

(C) 2017 Universidad Nacional Autónoma de México, Facultad de Contaduría y Administración. This is an open access article under the CC BY-NC-ND license (http://creativecommons.org/licenses/by-nc-nd/4.0/).
\end{abstract}

Keywords: Educational financing; Private expense; Financial markets; Mexico

JEL classification: I22

\footnotetext{
* Corresponding author.

E-mail addresses: kristiano.raccanello@coltlax.edu.mx (K. Raccanello), direccion@galileiac.org

(L.E. Carrillo Cubillas), yerena.mariana@gmail.com (M. Guzmán Yerena).

Peer Review under the responsibility of Universidad Nacional Autónoma de México.
} 


\section{Resumen}

A raíz de la crisis financiera del 2008, el ajuste macroeconómico ha afectado a los hogares mexicanos a través de un mayor desempleo y una caída del poder adquisitivo. También, las familias tenían que seguir financiando los gastos en educación, a veces endeudándose en el mercado financiero formal o informal. La hipótesis de este artículo propone que el acceso y el uso de los productos financieros formales e informales permiten reducir los problemas financieros asociados con los gastos escolares en los niveles de educación básica. El modelo probit se estima con una muestra constituida por cuatrocientos hogares que residen en el municipio de San Pedro Cholula (estado de Puebla). Los resultados indican que un empeoramiento de las condiciones laborales y la pérdida del empleo se asocian con una mayor probabilidad de enfrentar dificultades financieras. Asimismo, el acceso al mercado financiero formal permite reducir la probabilidad de enfrentar estas dificultades, mientras que para el informal los resultados están en función de las características de cada intermediario financiero.

(C) 2017 Universidad Nacional Autónoma de México, Facultad de Contaduría y Administración. Este es un artículo Open Access bajo la licencia CC BY-NC-ND (http://creativecommons.org/licenses/by-nc-nd/4.0/).

Palabras clave: Financiamiento de la educación; Gasto privado; Mercados financieros; México

Códigos JEL: $\mathrm{I} 22$

\section{Background information}

Education can be considered in different ways: i) as a consumer good that provides a benefit for the individuals without having any type of incidence in productivity; ii) as a means to help identify and grade skills and abilities; or iii) as a means to increase human capital (Carrillo, 2006) which, in turn, is considered a productive factor given the relation between the knowledge level of the workers and their capacity to use them and by extension, their productivity (Serrano, 1996). According to this last perspective, the education cost is an investment that generates better living conditions for the individual that receives it. In this sense, at an individual level, education is a process that contributes to the development of each human being, through which it is possible to access a higher income and better services, while at a collective level there is a general consensus to consider it as a lever for social development (Marcel \& Tokman, 2005).

Regarding the aforementioned, there is a close relation between the level of education and the income level of the individuals (Becker, 1964; Mincer, 1974), with evident intergenerational benefits associated to the level of education and prosperity of future generations (Hoyos, Martínez, \& Székely, 2010).

On the other hand, it is known that in Mexico, the percentage of income allocated to education decreases as the household income increases, with the exception of the last ten percent (Instituto Nacional de Estadística y Geografía [INEGI], 2010); that is, "education costs by the poorest strata is significantly lower than that corresponding to the high strata of society. However, (...) the low strata of society (...) focus their expenses on the basic level, whereas the high strata do it on higher education" (Bracho, 1995: 2-3, citing Llamas, 1993). Similarly, it is observed that the people in households with a lower income study fewer years and under worse conditions than those with higher income (Hochschild \& Scovronick, 2004).

\section{Education, human capital and economic results}

The importance of education at the individual level lies in being a permanent process that contributes to the development of a person, as well as being the main means to obtain, convey 
and enhance culture, and being a determining factor in the acquisition of knowledge and personal development. Human capital, which according to Becker (1964) is defined as “(...) the set of the productive capacities that an individual acquires through the accumulation of general or specific knowledge", is the bridge between education and work, with the latter being the culmination of what was learned during the school years, strengthened by experience and daily practice in the labor market.

The early years of life and the proper development of people are essential for their development as productive individuals. In these stages, the care of the parents, the access to a balanced diet and medical service, as well as the possibility of obtaining timely and quality education, make it possible for individuals, at an intergenerational level, to achieve better standards of living through a virtuous circle (Raccanello, 2012).

One of the manifestations through which this aspect can be appreciated is the economic results of micro-enterprises, which, in Mexico, represent $95.6 \%$ of the productive units and employ up to $45.6 \%$ of the workforce (Pavón, 2010); however, they only contribute with $15 \%$ of the Gross Domestic Product (Secretariat of Economy, 2010). In this regard, it is understood that as the level of education of the microentrepreneur increases, operating profits gradually increase when compared to those with only primary education, ${ }^{1}$ concluding that "with a higher level of education it is expected for the microentrepreneur to have skills that, along with a better understanding of the issues, will allow them to analyze and make better decisions that result in positive results for the microenterprise" (Raccanello \& Saucedo, 2015:17). These results are also supported by the data published by PROMÉXICO $(2014)^{2}$ and the Economic Databank (INEGI, 2014), where the correlation between the average school years per state with the productivity index is of $68.9 \%$, and with regard to the average of the gross income per economic activity it is of $41.5 \%$ for manufacture and $39 \%$ for commerce and services.

\section{Education in Mexico}

In the face of the results that have evidenced the shortcomings of the Mexican educational system at an international level (OCDE, 2000, 2003, 2006, 2009), this has been the target of an important reform approved in December 2012 and enacted in February 2013.

Even when it is still too soon to be able to determine the impact of the educational reform, the measures taken by the State before the reform already reflected an increase in the gross enrollment rate (or coverage) ${ }^{3}$ in primary and secondary education (Secretariat of Public Education [SEP, for its acronym in Spanish], 2010), where for basic education the figures reported by the SEP indicate that at a national level, during the 1990-1991 school cycle, there was a $95.9 \%$ coverage for the primary level, which increased to $98.6 \%$ for the 2009-2010 school cycle. Furthermore, at the secondary level, considering that in the 1990-1991 school cycle this was not obligatory, the national coverage increased from $68 \%$ to $95.3 \%$ (2009-2010 school cycle).

According to the figures published by the UNESCO (2010a), in 2009 the net rate ${ }^{4}$ of school enrollment at the primary level was of $93.9 \%$ (children between 6 and 12 years of age), $67.2 \%$

\footnotetext{
${ }^{1}$ Secondary: $+1,188$ pesos; Preparatory: $+1,447$ pesos; University: $+2,332$ pesos.

2 Main investment and commerce indicators of the States of Mexico (2014).

3 The gross enrollment rate (coverage) is calculated as follows: [(total enrollment of an educational level, regardless of age $) /($ total population with the age that corresponds to the educational level) $] \times 100$.

4 The net rate of enrollment is calculated as follows: [(enrollment corresponding to the age range of an educational level)/(total population with the age that corresponds to the educational level) $] \times 100$.
} 
for secondary (teenagers between 12 and 15 years of age), but only $25.7 \%$ of young people enrolled in preparatory. These percentages reflect that the higher the level of education, the greater the difference between the gross rate and the net rate of enrollment, that is, the percentage of the population enrolled that does not comply with the corresponding age of that academic level is greater. Additionally, it must be noted that secondary education and middle school are still not attainable for an significant sector of the population and many young people that join these school levels drop out ${ }^{5}$ and do not finish their studies (SEP, 2011).

\section{Causes of school dropouts}

The literature that has analyzed the causes associated to school dropouts indicates that they are mainly due to the lack of financial resources to cover the direct (enrollment and tuition fees) and indirect (work materials, uniforms and transport) costs of attending school, as well as the perception of a low educational quality (Baschieri \& Falkingham, 2007; Ersado, 2005; Morrisson, 2002; Rosati \& Rossi, 2007; Rumberger, 1995; Yuren, de la Cruz, Cruz, AraújoOlivera, and Estrada, 2005). Those students who have lesser abilities are the most likely to drop out of school (Bacolod and Ranjan, 2008), and having work activities could also affect attendance, school results and, ultimately, the permanence at the educational institution (Basu \& Van, 1998; Basu, 1999; Beegle, Dehejia, \& Gatti, 2005; Bhalotra, 2007; Edmonds \& Pavcnik, 2005; Gunnarsson, Orazem, \& Sánchez, 2006; Orazem \& Gunnarsson, 2003).

The financial crisis that hit the global economy in 2008 has modified the distribution of national budgets. According to the UNESCO (2011), several of the poorest countries in the world have had their plans for education funding affected, having to adjust their objectives for 2015 . In Mexico, the percentage of GDP allocated to education increased from 4.7\% for 2006-2007 to $4.9 \%$ in 2008, to reach $5.2 \%$ in the three-year period of 2009-2011 (UNESCO, 2010a). Despite this increase, the lack of employment and the loss of purchasing power due to the financial crisis could generate pressure and financial trouble in households. Although education costs are the result of a process of resource allocation that reflects a structure of priorities and social, family and individual objectives (Bracho, 1995), it should also take into consideration the economic resources available in the household.

For this, the financial crisis of 2008 resulted in a reduced growth of the GDP (1.2\%), when compared to the previous year $(3.3 \%$ in 2007$)$, but with a drop in $2009(-6.1 \%)$ followed by a partial recovery $(5.5 \%)$ in 2010 (Banco de México, 2011). The drop in production was followed by an increase in the inflation that decreased the purchasing power of the wages and by an increase in the open unemployment rate (OUR) mainly in 2009, same which in 2010 still did not manage to go back to the levels prior to the crisis. This increase in the OUR affected both genders; for men, it increased from 3.9\% (2008) to 5.5\% (2009), settling at 5.4\% for 2010. Similarly, for women, it went from $4.1 \%$ in 2008 to $5.5 \%$ (2009), settling at 5.4\% for 2010 (Botello, 2011). In addition to an increase in unemployment, the employed population observed lower wages (Botello, 2011; Table 6). Due to the above, it could be anticipated that these adjustments affect families at a macroeconomic level, especially if the one providing resources to the household lost their employment or, if they managed to relocate, depending on the new labor conditions.

This article associates the effects of the financial crisis with having faced some difficulty to cover the expenses of education; a situation that has already been addressed by the UNESCO

\footnotetext{
5 Dropout in primary school (2009-2010): 0.9\%; Dropout in secondary school (2009-2010): 6.2\%; Dropout in middle education (2009-2010): 15.6\% (SEP, 2011).
} 
(2010b) in its "Education for all Global Monitoring Report" when observing a reduction in the resources allocated to this sector, despite the fact that the cost per student in primary and secondary school shows an upward trend in the years following the financial crisis (UNESCO, 2010a). An explanation for this tendency is that the households could have resorted to formal or informal credit markets to pay for these expenses, in this sense, The National Survey on Financial Inclusion (SHCP, CNBV, \& INEGI, 2012) presents some evidence. Despite expenses in education being grouped in the "education or health expenses" category, which makes it impossible to isolate the interest variable, from the $38.6 \%$ of the population that had saved in the past year (2011), only $29.55 \%$ allocated these resources to education or health expenses. In the same manner, $35.96 \%$ applied for informal credits, of which $32.93 \%$ also allocated that money to education (or health) expenses. Regarding formal financing, $30.76 \%$ used the loaned money for this same purpose.

In addition to the above, Bray (2007) indicates that the expense in education can be divided into: i) opportunity costs, those activities that the individuals or families stop doing to invest in education, and ii) monetary expenses that can be done "inside" (collaborations and school fees) and "outside" of the school (purchase of uniforms, stationary, transport and paperwork). In the educational systems of industrialized countries, the expenses "inside" the school are fully covered by the government and the expenses "outside" the school comprise a small portion of the total expense of the households (Santibáñez, Campos, \& Jarillo, 2011). However, in countries where the capacity of the state to finance public education is limited, families have to try to co-finance the education of their members (OECD and UNESCO, 2002).

In relation to Puebla, which is the state that is the object of this article, it is listed as the sixth state with the lowest school attendance; on average, its inhabitants have 7.9 years of education (below the national average: 8.7 years), and has high levels of dropouts for the primary (1.2\%) and secondary school (4.7\%) levels (SEP, 2012). Particularly, for the municipality of San Pedro Cholula, where the empirical study was carried out, a greater number of dropouts than those at a state level can be observed, both for primary and secondary school, with $1.3 \%$ and 5.2\%, respectively (SEP, 2012).

\section{Formal and informal credits}

The access and use of financial services can provide an improvement of the well-being of the households. In particular, through this access, households are able to "(...) mobilize savings, receive credits, manage risks and participate in the payment systems" (CNBV, 2009), whereas the use component will be determined by the percentage of the population that uses some of these products or services. However, not all the population uses these services, and it is this population that is considered to be financially excluded, representing an important potential market for informal financial intermediaries.

In this sense, the National Commission for the Protection and Defense of Financial Service Users (CONDUSEF for its acronym in Spanish) indicates that:"(...) for most of the Mexican population there are two financial systems, formal and informal. The first tends to be almost always out of reach; the second is where most of the financial activity is carried out, and is usually developed in an area without supervision that is unobserved with regard to records and official statistics" (CONDUSEF, 2013), arguing that informal financial activity is an important source of credit comprised mainly by moneylenders and pawnshops.

In 2009, according to the First Financial Inclusion Report (CNVB, 2009), Puebla was the third state with the least municipalities that had bank branches, and the second with the least 
municipalities with ATMs. Similarly, it was the seventh state with the least debit card users $(43 \%)$.

In the municipality of San Pedro Cholula, with regard to the use of formal credit, there were 0.81 bank branches and the same ratio of ATMs, as well as 40 sale points per ten thousand adults (CNBV, 2010). Furthermore, 28.52\% of the financially active population had a debit card and $4.35 \%$ had a credit card. The comparative study between the state of Puebla and the national average $^{6}$ indicates that this municipality had an inferior coverage regarding the access and use of formal credit (CNBV, 2010:302).

Under these premises, the main objective of this study is to analyze if the difficulties of the households to pay for the education of their children lessen with the access and use of the formal and informal credit markets, considering the changes in the employment situation of the heads of the households in an environment that is subject to the repercussions of the financial crisis of 2008. To this end, the hypothesis of this work is that the use and access to financing sources, formal and informal, lessens the problems to afford education costs.

\section{Data and methodology}

\section{Data}

From a demographic of 62 primary schools (40 public and 22 private) in the municipality of San Pedro Cholula, the institutions were selected through a two-stage cluster systematic sampling with an elevation coefficient of 4 for the sampling of the private institutions and a value of 8 for the public ones, with the objective of randomly selecting 5 schools of each conglomerate. Once the schools were defined, 400 primary school students were selected through a simple probabilistic sampling and subsequently a survey was applied to one of the adults (preferably the parents) of the corresponding households. The gathering of information was carried out between the months of January and June of 2011; the capture of data was finalized in December of the same year.

\section{Survey}

The instrument comprised of 51 multiple-choice and dichotomous closed reagents organized into three sections: a) socio-economic aspects of the household (marital status and education of the parents, people that contribute with their income regularly and irregularly, assets, income, savings and house debts); 2) information regarding the children in the household (school level, school they attend, scholarships); and 3) financing mechanisms (access, use and characteristics of the formal and informal financing sources).

\section{Descriptive statistics}

According to the results of the survey, the majority of the households of the sample are comprised by couples $(84.75 \%$, though only $69 \%$ declared being married), with an average of four inhabitants per household (40\%) and two children (42.75\%). The majority of the parents have a preparatory $(46.48 \%$ of the fathers and $39.80 \%$ of the mothers $)$ or secondary $(24.62 \%$ and $31.74 \%$, respectively) maximum level of education.

\footnotetext{
61.77 branches per ten thousand adults.
} 
As for the financial aspects, $49.25 \%$ of households only have one member that contributes to their income regularly, and irregular contributions were detected in $17 \%$ of cases. In addition to the foregoing, the income level of the households is low; 59\% of the sample observes up to 4 minimum wages (less than 6317 pesos per month) and $23.25 \%$ observes between 5 and 7 minimum wages (between 6317 and 11,053 pesos).

On the other hand, more than half of the households (51.25\%) do not have savings and $33.25 \%$ has accumulated less than 11,369 pesos. These figures represent very limited funds in the event of a contingency. Regarding debts, $73.75 \%$ of respondents stated having debts between 3001 and 25,000 pesos; the percentages are gradually reduced for greater amounts. Additionally, only $21 \%$ of respondents that stated having a credit card or a department store credit card, indicated having problems paying their balances in 2008, a percentage that increases to $36.75 \%$ and $52.75 \%$ in the following years (2009 and 2010, respectively). This tendency follows the worsening of the financial crisis and unemployment rate during those years.

Regarding work activities, the majority of the household parents are wage earners from the private sector $(40.75 \%)$, self-employed $(28 \%)$ and, to a lesser extent, some work in the public sector $(19.75 \%)$. In the last year, $74 \%$ remained in the same job, sometimes having to accept changes in their work conditions $(7.25 \%)$ or incorporating another activity to complement the level of income $(6.5 \%)$. Of the remaining, $10.5 \%$ lost their job, managing to relocate to another job $(6 \%)$, or remained unemployed $(4.5 \%)$ until the date of the survey.

The situation of mothers is a little bit different due to the fact that the majority of them are homemakers $(30.5 \%)$, or they work in the public sector $(16 \%)$. A smaller percentage of women, in relation to men, has remained in their same job (56.25\%), having accepted changes in their work conditions $(4.5 \%)$. A greater percentage of women, in relation to men, that incorporate other work activities to complement their income $(13 \%)$ is also noted. The percentage of women who lost their job was of $8.25 \%$, and only $2.5 \%$ managed to relocate to another job, while $5.75 \%$ remained unemployed.

It was found that in the surveyed households there was one $(33 \%)$, two $(40.25 \%)$, or three $(21.75 \%)$ children who are currently in school. The data reveal that the percentage of those children who attend private school decreases as the number of children per household increases. This is possibly due to the financial burden that having kids in these institutions represents. In relation to this, $36.25 \%$ of households state that they had problems paying the costs of education during the 2010-2011 school cycle, trying to cover said costs by borrowing money from family $(48.97 \%)$, participating in a group savings pool $(15.86 \%)$, or financing them with credit cards $(13.10 \%)$. In relation to these problems, minors only stopped attending school in $1.38 \%$ of the cases, while $2.78 \%$ had to incorporate some type of paid work to their academic activities.

\section{Methodology}

In order to be able to prove the hypothesis of this work a probit model was estimated, with robust standard errors, in which the dependent variable problem2010_2011 takes the value of 1 if the household had financial problems paying the education of their children during the 2010-2011 school year, and 0 if this was not the case. The coefficients represent the marginal changes, if they are significant and positive (negative), whether or not they have problems paying for the education of their children. The descriptions of each of the independent variables included in the model are presented in Table A.1 of the annex. 


\section{Results}

According to the Hosmer-Lemeshow test, the model adjusts well to the data $(p=0.7616)$, and this specification allows to correctly classify $84.5 \%$ of the observations of the dependent variable (Table 1).

According to the estimations, the problems for the payment of education present an inertial behavior: if the household had difficulties paying the education costs of the 2009-2010 school cycle, the probability of the problem reoccurring on the following school cycle is of $42 \%$; whereas if the problem occurred two cycles before (2008-2009), though lower, the probability remains relatively high $(20.8 \%)$. Evidently, this situation reflects a certain degree of vulnerability of the households that do not manage to eliminate this problem completely, despite the passage of time.

Although the levels of education of both parents were included in the model, only those of the mother are associated to the problems regarding the payment of education. With regard to those of them who have a university degree, these problems are verified with a higher probability $(11.9 \%)$ in the cases where the mothers have a middle level of education, probably due to a deficient management of resources. However, if they have a primary or lower school level, the probability of presenting this problem decreases to a $26.9 \%$. This behavior can be explained through the preferences of the parents when selecting the type of institution that their children will attend. If the mothers have low education levels, they could send their children to public schools, where the costs of education are lower and the financial commitment is also easier to meet. In all estimated models throughout this research, the coefficient associated to this variable has always presented a negative sign (significant at $1 \%$ ). An analysis of the sample information showed that from 30 households where the mother had this education level, 27 of them had their kids attending a public school, which supports the aforementioned interpretation.

On the other hand, none of the income variables turned out to be statistically significant, and therefore no association between these and the problems in paying for the education of the children was detected. As a matter of fact, it seems that the households with the lowest incomes tend to have fewer problems with regard to the payment of school costs, possibly because they select public institutions within their budgets. Despite this, the aspects related to the financial stability of a household are important. For each individual that contributes with irregular income to the household, there is a $22.1 \%$ higher probability of having problems paying the education of the children in said household, and in this same manner, when the household has assets, or uses services that involve regular payments for their use (vehicle, telephone, and cable), a lower probability of having these types of financial difficulties $(28.2 \%, 5.8 \%$ and $15.6 \%$, respectively) is observed.

Regarding debt in the households, concerning amounts lower than 3000 pesos, the immediately superior ranges (3001-6000 and 6001-15,000 pesos) are also not statistically significant, which suggests that they are financial obligations that the households are able to manage. However, amounts greater than 15,000 pesos are strongly associated to problems in the household to pay for the education of the children, as the marginal changes vary between 42 and $55.7 \%$, depending on the range of debt.

Due to the fact that the costs that the households confront are related to the number of children, their school level, and the type of institution (private or public) they attend, the model included the number of children enrolled by level and type of educational institution.

The estimations indicated that for each child enrolled in a private school at the nursery or preschool level, the probability of facing these problems increases by $26.1 \%$, and for those 
Table 1

Estimations of the probit model.

\begin{tabular}{|c|c|c|c|c|c|}
\hline problema2010_2011 & $\mathrm{d} F / \mathrm{d} x$ & Robust Std. Error & & $\mathrm{dF} / \mathrm{dx}$ & Robust Std. Error \\
\hline Problem2009_2010 & 0.420 & $0.067^{* * * *}$ & Cprep_priv & -0.080 & 0.137 \\
\hline Problem2008_2009 & 0.208 & $0.091^{* * *}$ & Cprep_pub & -0.015 & 0.088 \\
\hline Problem2007_2008 & 0.023 & 0.105 & C_private_schools & -0.160 & 0.162 \\
\hline F_uptoprimaryschool & 0.068 & 0.115 & C_public_schools & 0.174 & 0.222 \\
\hline Fsecondaryschool & -0.051 & 0.074 & Scholarship_nursery\&preschool_priv & $-2.11 \mathrm{E}-05$ & $8.59 \mathrm{E}-05$ \\
\hline M_uptoprimaryschool & -0.269 & $0.039^{* * *}$ & Scholarship_nursery\&preschool_pub & $-1.11 \mathrm{E}-05$ & $1.28 \mathrm{E}-04$ \\
\hline Msecondaryschool & 0.119 & $0.066^{*}$ & Scholarship_prim_priv & $-3.75 \mathrm{E}-05$ & $3.75 \mathrm{E}-05$ \\
\hline Regular_contributions & 0.045 & 0.041 & Scholarship_prim_pub & $-1.81 \mathrm{E}-06$ & $4.28 \mathrm{E}-05$ \\
\hline Irregular_contributions & 0.221 & $0.077^{* * * *}$ & Scholarship_sec_priv & $2.47 \mathrm{E}-05$ & $4.49 \mathrm{E}-05$ \\
\hline Own & -0.083 & 0.113 & Scholarship_sec_pub & $8.81 \mathrm{E}-04$ & $6.38 \mathrm{E}-04$ \\
\hline Rent & -0.033 & 0.107 & Scholarship _prep_priv & $1.17 \mathrm{E}-04$ & $6.20 \mathrm{E}-05^{*}$ \\
\hline Income_upto2mw & -0.155 & 0.098 & Scholarship _prep_pub & $2.55 \mathrm{E}-04$ & $1.96 \mathrm{E}-04$ \\
\hline Income2-4mw & -0.160 & $0.078^{*}$ & Scholarship _he_priv & $1.71 \mathrm{E}-04$ & $8.96 \mathrm{E}-05^{*}$ \\
\hline Income $4-7 \mathrm{mw}$ & -0.032 & 0.087 & Scholarship_he_pub & $-5.76 \mathrm{E}-05$ & $8.32 \mathrm{E}-05$ \\
\hline Income7-10mw & 0.072 & 0.098 & Microfinancing & $5.32 \mathrm{E}-06$ & $6.93 \mathrm{E}-06$ \\
\hline Nosavings & -0.005 & 0.070 & Savings schemes & $4.56 \mathrm{E}-05$ & $2.64 \mathrm{E}-05^{*}$ \\
\hline Couple & -0.065 & 0.091 & Fam_and_friends & $-1.64 \mathrm{E}-05$ & $7.20 \mathrm{E}-06^{* *}$ \\
\hline Vehicle & -0.282 & $0.089^{* * * *}$ & Pawnshops & $-1.24 \mathrm{E}-05$ & $7.98 \mathrm{E}-06$ \\
\hline Telephone & -0.158 & $0.097^{*}$ & Banks & $1.07 \mathrm{E}-06$ & $3.79 \mathrm{E}-07^{* * * *}$ \\
\hline Cable & -0.156 & $0.072^{* *}$ & Credit_cards & -0.420 & $0.075^{* * *}$ \\
\hline Debt_3001-6000 & 0.093 & 0.151 & Debit_cards & -0.124 & $0.079^{*}$ \\
\hline Debt_6001-15000 & 0.241 & 0.177 & Department_store_credit_card & 0.041 & 0.079 \\
\hline Debt_15001-25000 & 0.420 & $0.202^{* *}$ & F_lostjob & 0.285 & $0.172^{*}$ \\
\hline Debt_25001-40000 & 0.557 & $0.186^{* * * *}$ & F_changedjobs & 0.031 & 0.122 \\
\hline Debt_40001-60000 & 0.502 & $0.197^{* * *}$ & F_lowerwage & 0.493 & $0.289^{*}$ \\
\hline Debt_higherthan60000 & 0.558 & $0.192^{* *}$ & F_fewerbenefits & -0.007 & 0.251 \\
\hline Cnursery\&preschool_priv & 0.261 & $0.097^{* * *}$ & M_lostjob & -0.002 & 0.121 \\
\hline Cnursery\&preschool_pub & 0.106 & 0.079 & M_changedjobs & 0.095 & 0.200 \\
\hline Cprim_priv & 0.314 & $0.062^{* * * *}$ & M_lowerwage & 0.230 & 0.269 \\
\hline Cprim_pub & 0.123 & $0.062^{* * *}$ & M_fewerbenefits & 0.103 & 0.221 \\
\hline Csec_priv & -0.106 & 0.082 & Int_household & -0.003 & 0.030 \\
\hline Csec_pub & -0.172 & $0.078^{* *}$ & & & \\
\hline$N=400$ & & & \multirow{3}{*}{\multicolumn{3}{|c|}{$\begin{array}{l}\text { Correctly classified }=84.50 \% \\
\text { Hosmer-Lemeshow }- \text { Goodness-of-fit test }- \text { Pearson chi2 }(283)=265.77 \\
\text { Prob }>\text { chi2 }=0.7616\end{array}$}} \\
\hline Wald chi2 $(63)=278.09^{* * *}$ & & & & & \\
\hline Pseudo $R^{2}=0.5424$ & & & & & \\
\hline
\end{tabular}

Source: Own estimation.

* 0.1 .

** 0.05 .

*** 0.01 
attending primary school in public or private institutions, the probability is of $12.3 \%$ and $31.4 \%$, respectively.

Similarly, if on the one hand we consider that private institutions are more expensive compared to public institutions, which reflects on marginal changes, we can also acknowledge that the majority of households with children in primary school or lower educational levels are comprised by younger couples, who could face greater financial problems that tend to decrease with time. This is because at a secondary level, for each student enrolled in a public institution, the probability decreases by $17.2 \%$ (for children in secondary school at a private institution a decrease in the probability is also detected, but it is not significant).

Although the study focused on households with children who are studying at a basic educational level, the variables corresponding to higher educational levels were included because some other members of the family were enrolled in them. In general, it can be observed that the probability of presenting problems to cover the payments related to the education of the family members at the lower educational levels tends to decrease regardless of the type of institution, though none of the variables were significant. This result is possible because only the households with a better financial situation are able to push the education of their children forward.

Although it would be expected for scholarships to reduce financial problems, according to the estimations, said scholarships present a weak association and only for students enrolled in private schools at the preparatory and university levels. These educational levels offered by private institutions are usually the most expensive, and those households that apply for scholarships do so due to financial difficulties. In this case, the positive relation between the amount of the scholarships and the problems in paying the costs of education of the children would indicate that these aids are being assigned to households that actually need them.

The analyzing of the variables that correspond to the access and use of the formal financial sector - measured through having a credit or debit card - yields the fact that the possession of bank cards allows users to reduce the possibilities of having difficulties to pay the education costs of their children. In particular, the access to a line of credit is associated to a greater reduction $(-42 \%)$, as it is a source of available resources in case of need. Savings, though these are relatively low according to the results of the survey, also contribute to reduce the probability, but they do so to a lesser extent $(-12.4 \%)$.

Regarding the use of financial support, bank loans present a similar behavior, but they only reduce probability marginally ( $0.1 \%$ for every 1000 pesos in funding). Despite the small reduction, these results suggest that financial inclusion, mainly through the availability of financial savings and credit instruments, is associated to a smaller probability that the household will face difficulties in paying the costs derived from the school activities of their children. However, considering the use of informal loans, it is observed that if the funds are loaned by family, there is a $1.64 \%$ drop in probability is associated for every 1000 pesos.

Regarding the foregoing, loans by family members may be provided more readily when compared to a bank, and are therefore more effective than the latter with regard to the financial needs in the household. This interpretation also allows explaining the $4.56 \%$ increase of probability if the resources (1000 pesos) have been obtained through a group savings pool, in which the money is given by the assigned "turn" and therefore does not coincide with the moment in which the need arises. Likewise, participating in a group savings pool implies having to provide periodic contributions for its entire duration. In this manner, forced savings can contribute to the financial problems of the household.

As for the changes in the work conditions, it was found that for the father of the household, having lost his work and remaining unemployed, or having found another job with a lower 
wage during the 2010-2011 school cycle, even if the changes are only slightly significant, are associated with a high probability of problems in paying the costs of education $(28.5 \%$ and $49.3 \%$, respectively).

For most households, the decision to enroll their children in school is made mid-spring and is settled some months before the school cycle (August-June). Once the children are enrolled, sudden changes in financial stability due to the loss of employment-considering the acquired financial obligations - force the household to re-assign the family budget considering their new problematic. This is reflected in the model through the magnitude of the estimated marginal changes.

Finally, despite the fact that most of the variables that represent the changes in the work situation of the mother having positive signs, none of them are statistically significant, which, at least in the municipality where the study was carried out, could be due to the fact that their participation in the finances of the household may not be as relevant as that of their male counterpart.

\section{Conclusions}

According to the results of this work, since the financial and unemployment crisis, households that have access to the formal financial market manage to significantly reduce their problems to cover the costs of education. Similarly, the financing mechanisms tend to reduce the probability of having problems in covering the costs of education, though their specific characteristics must be taken into consideration.

In this manner and once again addressing the fact that education is one of the means through which individuals are able to access higher levels of income, and knowing that a greater preparation of the microentrepreneur is positively associated to the operative profits of the microenterprises, the access and the use of the financial services can also have an important role in the accumulation of human capital and its relation to the results of the productive units in Mexico.

Even if the existence of inertia was detected in the probability of having problems to cover the costs of education-which evidences that this difficulty is not short-term-, the problem seems to lie more on the lack of financial stability and not so much in the low levels of income of the household. This result may derive from the fact that the payment of education costs is a long-term commitment for the family and as such, if the family achieves a financially stable household, the probability that it will have problems to cover the cost of education is lower. In this sense, debts (especially when they are greater to 15,000 pesos) comprise a financial load that is difficult to handle and which is associated to greater problems related to the payment of other expenses.

Lastly, it was also observed that the effects of the financial crisis are reflected in a greater probability to face problems regarding the payment of the education costs of children, particularly when the father is unemployed or when he receives a lower wage despite having relocated to a new job.

One final observation: Households face different types and magnitudes of expenses so that their children are able to access education, which depends on the type of institution selected (public or private). It is well-known that attending a public institution represents a smaller financial effort when compared to a private one. However, lower costs are also associated to a lower income, as households with fewer resources select the cheaper educational option. In addition to the enrollment fee and tuition, which probably comprise the greatest 
difference between public and private education, there are other common items between the two (school supplies and uniforms). For such purposes, state governments look to eliminate these costs by providing free school supplies and uniforms to the students at the basic levels. Other benefits that students from public schools receive can be tablets or other learning tools.

The costs associated to geographical aspects (route, distance between school and home, transport, and transportation time), and to the model and quality (excursions, ad-hoc materials) of the offered education service, are identified. The discounts that some private schools offer when two or more siblings are enrolled are no less important; a situation that also allows parents to save time. Lastly, there are costs associated to the presents given to the teachers in one or more occasions throughout the school cycles, motivated by social reasons and tradition.

Due to the fact that educational programs are particularly dynamic, parents are continually exposed to new and differentiated academic options. Considering that the experiences of the parents in this educational service market are generally modest, they become the buyers of a service not consumed directly by themselves. The scarce knowledge of the progenitors about these aspects may cause the student to change school or educational program, which, again, could result in higher costs. Some of these aspects have not been considered in this work, but they may serve as guidelines to explore new research hypotheses to be analyzed in future investigations.

\section{Annex.}

See Table A.1. 
Table A. 1

\begin{tabular}{|c|c|c|c|c|c|c|}
\hline Variable & Variable description & $N$ & Average & s.d. & Min & Max \\
\hline Problem2010_2011 (dep.var) & $\begin{array}{l}1 \text { if the household had problems covering the education } \\
\text { costs of their children during the 2010-2011 school } \\
\text { cycle, } 0 \text { otherwise. }\end{array}$ & 400 & 0.363 & 0.481 & 0 & 1 \\
\hline Problem2009_2010 & $\begin{array}{l}1 \text { if the household had problems covering the education } \\
\text { costs of their children during the 2009-2010 school } \\
\text { cycle, } 0 \text { otherwise. }\end{array}$ & 400 & 0.528 & 0.500 & 0 & 1 \\
\hline Problem2008_2009 & $\begin{array}{l}1 \text { if the household had problems covering the education } \\
\text { costs of their children during the 2008-2009 school } \\
\text { cycle, } 0 \text { otherwise. }\end{array}$ & 400 & 0.368 & 0.483 & 0 & 1 \\
\hline Problem2007_2008 & $\begin{array}{l}1 \text { if the household had problems covering the education } \\
\text { costs of their children during the 2007-2008 school } \\
\text { cycle, } 0 \text { otherwise. }\end{array}$ & 400 & 0.210 & 0.408 & 0 & 1 \\
\hline F_untilprimaryschool & $\begin{array}{l}1 \text { if the father attended school until primary level, } 0 \\
\text { otherwise. }\end{array}$ & 400 & 0.113 & 0.316 & 0 & 1 \\
\hline Fsecondary & $\begin{array}{l}1 \text { if the father attended school until secondary } \\
\text { or preparatory level, } 0 \text { otherwise. }\end{array}$ & 400 & 0.413 & 0.493 & 0 & 1 \\
\hline M_untilprimaryschool & $\begin{array}{l}1 \text { if the mother attended school until primary level, } 0 \\
\text { otherwise }\end{array}$ & 400 & 0.075 & 0.264 & 0 & 1 \\
\hline Msecondary & $\begin{array}{l}1 \text { if the mother attended school until secondary } \\
\text { or preparatory level, } 0 \text { otherwise. }\end{array}$ & 400 & 0.568 & 0.496 & 0 & 1 \\
\hline Fhe (Mhe) & $\begin{array}{l}1 \text { if the father (mother) has higher education, } 0 \\
\text { otherwise (base category). }\end{array}$ & & & & & \\
\hline Regular_contributions & $\begin{array}{l}\text { Number of people that contribute money to the } \\
\text { household regularly }\end{array}$ & 400 & 1.610 & 0.748 & 0 & 6 \\
\hline Irregular_contributions & $\begin{array}{l}\text { Number of people that contribute money to the } \\
\text { household irregularly }\end{array}$ & 400 & 0.193 & 0.448 & 0 & 2 \\
\hline Own & $\begin{array}{l}1 \text { if the household lives in their own house/apartment, } 0 \\
\text { otherwise }\end{array}$ & 400 & 0.558 & 0.497 & 0 & 1 \\
\hline Rent & $\begin{array}{l}1 \text { if the household lives in a rented house/apartment, } 0 \\
\text { otherwise }\end{array}$ & 400 & 0.328 & 0.470 & 0 & 1 \\
\hline
\end{tabular}


Table A.1 (Continued)

\begin{tabular}{|c|c|c|c|c|c|c|}
\hline Variable & Variable description & $N$ & Average & s.d. & Min & $\operatorname{Max}$ \\
\hline Anotherhouse & $\begin{array}{l}1 \text { if the household lives with family, } 0 \text { otherwise (base } \\
\text { category) }\end{array}$ & & & & & \\
\hline Income_upto $2 \mathrm{mw}$ & $\begin{array}{l}1 \text { if the household income is lower or equal to } 2 \\
\text { minimum wages ( } 3158 \text { pesos), } 0 \text { otherwise }\end{array}$ & 400 & 0.203 & 0.402 & 0 & 1 \\
\hline Income $2-4 \mathrm{mw}$ & $\begin{array}{l}1 \text { if the household income is between } 2 \text { and } 4 \text { minimum } \\
\text { wages (3159-6316 pesos), } 0 \text { otherwise }\end{array}$ & 400 & 0.155 & 0.362 & 0 & 1 \\
\hline Income $4-7 \mathrm{mw}$ & $\begin{array}{l}1 \text { if the household income is between } 4 \text { and } 7 \text { minimum } \\
\text { wages }(6317-11,053 \text { pesos), } 0 \text { otherwise. }\end{array}$ & 400 & 0.233 & 0.423 & 0 & 1 \\
\hline Income7-10mw & $\begin{array}{l}1 \text { if the household income is between } 7 \text { and } 10 \\
\text { minimum wages }(11,054-15,740 \text { pesos }), 0 \text { otherwise. }\end{array}$ & 400 & 0.163 & 0.369 & 0 & 1 \\
\hline Income_greater $10 \mathrm{mw}$ & $\begin{array}{l}1 \text { if the household income is higher than } 10 \text { minimum } \\
\text { wages (>15,740 pesos), } 0 \text { otherwise (base category). }\end{array}$ & & & & & \\
\hline nosavings & 1 if the household has no savings, 0 if it does. & 400 & 0.513 & 0.500 & 0 & 1 \\
\hline Couple & $\begin{array}{l}1 \text { if the household is comprised by both parents (married } \\
\text { or free union), } 0 \text { otherwise. }\end{array}$ & 400 & 0.848 & 0.360 & 0 & 1 \\
\hline Vehicle & 1 if the household has a vehicle or truck, 0 otherwise. & 400 & 0.635 & 0.482 & 0 & 1 \\
\hline Telephone & 1 if the household has a phone line, 0 otherwise. & 400 & 0.743 & 0.438 & 0 & 1 \\
\hline cable & 1 if the household has cable service and 0 otherwise. & 400 & 0.455 & 0.499 & 0 & 1 \\
\hline Debt_lowerthan 3000 & $\begin{array}{l}1 \text { if the household has a debt lower than } 3000 \text { pesos, } 0 \\
\text { otherwise (base category). }\end{array}$ & & & & & \\
\hline Debt_3001-6000 & $\begin{array}{l}1 \text { if the household has a debt between } 3001 \\
\text { and } 6000 \text { pesos, } 0 \text { otherwise. }\end{array}$ & 400 & 0.388 & 0.488 & 0 & 1 \\
\hline Debt_6001-15000 & $\begin{array}{l}1 \text { if the household has a debt between } 6001 \\
\text { and } 15,000 \text { pesos, } 0 \text { otherwise. }\end{array}$ & 400 & 0.213 & 0.410 & 0 & 1 \\
\hline Debt_15001-25000 & $\begin{array}{l}1 \text { if the household has a debt between } 15,001 \\
\text { and } 25,000 \text { pesos, } 0 \text { otherwise. }\end{array}$ & 400 & 0.138 & 0.345 & 0 & 1 \\
\hline Debt_25001-40000 & $\begin{array}{l}1 \text { if the household has a debt between entre } 25,001 \text { and } \\
40,000 \text { pesos, } 0 \text { otherwise. }\end{array}$ & 400 & 0.073 & 0.260 & 0 & 1 \\
\hline Debt_40001-60000 & $\begin{array}{l}1 \text { if the household has a debt between } 40,001 \\
\text { y } 60,000 \text { pesos, } 0 \text { otherwise. }\end{array}$ & 400 & 0.080 & 0.272 & 0 & 1 \\
\hline Debt_higherthan60000 & $\begin{array}{l}1 \text { if the household has a debt greater than } 60,000 \text { pesos, } \\
0 \text { otherwise. }\end{array}$ & 400 & 0.068 & 0.251 & 0 & 1 \\
\hline Cnursery\&preschool_priv & $\begin{array}{l}\text { Number of children in private institutions at a nursery } \\
\text { or preschool level during the } 2010-2011 \text { school cycle. }\end{array}$ & 400 & 0.108 & 0.333 & 0 & 2 \\
\hline
\end{tabular}


Table A.1 (Continued)

\begin{tabular}{|c|c|c|c|c|c|c|}
\hline Variable & Variable description & $N$ & Average & s.d. & Min & $\operatorname{Max}$ \\
\hline Cnursery\&preschool_pub & $\begin{array}{l}\text { Number of children in public institutions at a nursery } \\
\text { or preschool level during the } 2010-2011 \text { school cycle. }\end{array}$ & 400 & 0.175 & 0.424 & 0 & 2 \\
\hline Cprim_priv & $\begin{array}{l}\text { Number of children in private institutions at a primary } \\
\text { level during the 2010-2011 school cycle. }\end{array}$ & 400 & 0.545 & 0.734 & 0 & 3 \\
\hline Cprim_pub & $\begin{array}{l}\text { Number of children in public institutions at a primary } \\
\text { level during the 2010-2011 school cycle. }\end{array}$ & 400 & 0.575 & 0.810 & 0 & 4 \\
\hline Csec_priv & $\begin{array}{l}\text { Number of children in private institutions at a secondary } \\
\text { level during the 2010-2011 school cycle. }\end{array}$ & 400 & 0.160 & 0.458 & 0 & 2 \\
\hline Csec_pub & $\begin{array}{l}\text { Number of children in public institutions at a secondary } \\
\text { level during the } 2010-2011 \text { school cycle. }\end{array}$ & 400 & 0.148 & 0.414 & 0 & 2 \\
\hline Cprep_priv & $\begin{array}{l}\text { Number of children in private institutions at a } \\
\text { preparatory level during the 2010-2011 school cycle. }\end{array}$ & 400 & 0.113 & 0.361 & 0 & 2 \\
\hline Cprep_pub & $\begin{array}{l}\text { Number of children in public institutions at a } \\
\text { preparatory level during the 2010-2011 school cycle. }\end{array}$ & 400 & 0.108 & 0.341 & 0 & 2 \\
\hline H_private_schools & $\begin{array}{l}\text { Number of children in the household in private } \\
\text { education institutions during the 2010-2011 school } \\
\text { cycle. }\end{array}$ & 400 & 0.058 & 0.244 & 0 & 2 \\
\hline H_public_schools & $\begin{array}{l}\text { Number of children in the household in public education } \\
\text { institutions during the 2010-2011 school cycle. }\end{array}$ & 400 & 0.050 & 0.218 & 0 & 1 \\
\hline Scholarship_preschool_priv & $\begin{array}{l}\text { Scholarship, in pesos, assigned to children in nursery or } \\
\text { preschool that attend a private institution during the } \\
2010-2011 \text { school cycle. }\end{array}$ & 400 & 77.38 & 637.43 & 0.00 & 7000.00 \\
\hline Scholarship_preschool_pub & $\begin{array}{l}\text { Scholarship, in pesos, assigned to children in nursery or } \\
\text { preschool that attend a public institution during the } \\
2010-2011 \text { school cycle. }\end{array}$ & 400 & 58.00 & 729.22 & 0.00 & $14,300.00$ \\
\hline Scholarship_prim_priv & $\begin{array}{l}\text { Scholarship, in pesos, assigned to children in primary } \\
\text { school that attend a private institution during the } \\
2010-2011 \text { school cycle. }\end{array}$ & 400 & 275.88 & 817.45 & 0.00 & 7000.00 \\
\hline Scholarship_prim_pub & $\begin{array}{l}\text { Scholarship, in pesos, assigned to children in primary } \\
\text { school that attend a public institution during the } \\
2010-2011 \text { school cycle. }\end{array}$ & 400 & 215.20 & 2262.11 & 0.00 & $42,900.00$ \\
\hline Scholarship_sec_priv & $\begin{array}{l}\text { Scholarship, in pesos, assigned to children in secondary } \\
\text { school that attend a private institution during the }\end{array}$ & 400 & 152.52 & 1246.95 & 0.00 & $14,000.00$ \\
\hline
\end{tabular}


Table A.1 (Continued)

\begin{tabular}{|c|c|c|c|c|c|c|}
\hline Variable & Variable description & $N$ & Average & s.d. & Min & Max \\
\hline Scholarship_sec_pub & $\begin{array}{l}\text { Scholarship, in pesos, assigned to children in secondary } \\
\text { school that attend a public institution during the } \\
2010-2011 \text { school cycle. }\end{array}$ & 400 & 21.63 & 206.93 & 0.00 & 2500.00 \\
\hline Scholarship_prep_priv & $\begin{array}{l}\text { Scholarship, in pesos, assigned to children in } \\
\text { preparatory school that attend a private institution } \\
\text { during the 2010-2011 school cycle. }\end{array}$ & 400 & 100.21 & 563.03 & 0.00 & 6000.00 \\
\hline Scholarship_prep_pub & $\begin{array}{l}\text { Scholarship, in pesos, assigned to children in } \\
\text { preparatory school that attend a public institution } \\
\text { during the 2010-2011 school cycle. }\end{array}$ & 400 & 20.80 & 167.02 & 0.00 & 1850.00 \\
\hline Scholarship_he_priv & $\begin{array}{l}\text { Scholarship, in pesos, assigned to children at a higher } \\
\text { education level that attend a private institution during } \\
\text { the } 2010-2011 \text { school cycle. }\end{array}$ & 400 & 74.03 & 449.45 & 0.00 & 4800.00 \\
\hline Scholarship_he_pub & $\begin{array}{l}\text { Scholarship, in pesos, assigned to children at a higher } \\
\text { education level that attend a public institution during } \\
\text { the } 2010-2011 \text { school cycle. }\end{array}$ & 400 & 62.90 & 595.65 & 0.00 & 8000.00 \\
\hline Microfinancing & $\begin{array}{l}\text { Credit, in pesos, granted to the household by } \\
\text { micro-financial institutions/microcredit in the last } \\
12 \text { months. }\end{array}$ & 400 & 437.25 & 2868.91 & 0.00 & $48,000.00$ \\
\hline Group savings pool & $\begin{array}{l}\text { Credit, in pesos, granted to the household by a group } \\
\text { savings pool in the last } 12 \text { months. }\end{array}$ & 400 & 200.25 & 950.75 & 0.00 & $10,000.00$ \\
\hline Fam_and_friends & $\begin{array}{l}\text { Credit, in pesos, granted to the household by family } \\
\text { and/or friends in the last } 12 \text { months. }\end{array}$ & 400 & 2134.69 & $10,847.11$ & 0.00 & $200,000.00$ \\
\hline Pawnshops & $\begin{array}{l}\text { Credit, in pesos, granted to the household by a } \\
\text { pawnshop in the last } 12 \text { months. }\end{array}$ & 400 & 193.14 & 2108.19 & 0.00 & $40,000.00$ \\
\hline Banks & $\begin{array}{l}\text { Credit, in pesos, granted to the household by banks } \\
\text { in the last } 12 \text { months. }\end{array}$ & 400 & 6204.43 & $63,073.20$ & 0.00 & $1060,000.00$ \\
\hline Credit_cards & $\begin{array}{l}1 \text { if the household has at least one credit card, } 0 \\
\text { otherwise. }\end{array}$ & 400 & 0.503 & 0.501 & 0 & 1 \\
\hline Debit_cards & $\begin{array}{l}1 \text { if the household has at least one debit card, } 0 \\
\text { otherwise. }\end{array}$ & 400 & 0.573 & 0.495 & 0 & 1 \\
\hline Department_store_credit_cards & $\begin{array}{l}1 \text { if the household has at least one department store } \\
\text { credit card, } 0 \text { otherwise. }\end{array}$ & 400 & 0.533 & 0.500 & 0 & 1 \\
\hline F_lostjob & $\begin{array}{l}1 \text { if the father lost his job during the } 2010-2011 \text { school } \\
\text { cycle and remains unemployed, } 0 \text { otherwise. }\end{array}$ & 400 & 0.045 & 0.208 & 0 & 1 \\
\hline
\end{tabular}


Table A.1 (Continued)

\begin{tabular}{|c|c|c|c|c|c|c|}
\hline Variable & Variable description & $N$ & Average & s.d. & Min & $\operatorname{Max}$ \\
\hline F_changedjobs & $\begin{array}{l}1 \text { if the father lost his job and changed jobs during the } \\
2010-2011 \text { school cycle, } 0 \text { otherwise. }\end{array}$ & 400 & 0.060 & 0.238 & 0 & 1 \\
\hline F_lowerwage & $\begin{array}{l}1 \text { if the father did not lose his job but his salary was } \\
\text { reduced during the 2010-2011 school cycle, } 0 \\
\text { otherwise. }\end{array}$ & 400 & 0.023 & 0.148 & 0 & 1 \\
\hline F_fewerbenefits & $\begin{array}{l}1 \text { if the father did not lose his job but his benefits were } \\
\text { reduced or taken away during the } 2010-2011 \text { school } \\
\text { cycle, } 0 \text { otherwise. }\end{array}$ & 400 & 0.013 & 0.111 & 0 & 1 \\
\hline M_lostjob & $\begin{array}{l}1 \text { if the mother lost her job during the } 2010-2011 \text { school } \\
\text { cycle and remains unemployed, } 0 \text { otherwise. }\end{array}$ & 400 & 0.058 & 0.233 & 0 & 1 \\
\hline M_changedjobs & $\begin{array}{l}1 \text { if the mother lost her job and changed jobs during the } \\
2010-2011 \text { school cycle, } 0 \text { otherwise. }\end{array}$ & 400 & 0.025 & 0.156 & 0 & 1 \\
\hline M_lowerwage & $\begin{array}{l}\text { 1if the mother did not lose her job but her salary was } \\
\text { reduced during the 2010-2011 school cycle, } 0 \\
\text { otherwise. }\end{array}$ & 400 & 0.020 & 0.140 & 0 & 1 \\
\hline M_fewerbenefits & $\begin{array}{l}1 \text { if the mother did not lose her job but her benefits were } \\
\text { reduced or taken away during the 2010-2011 school } \\
\text { cycle, and } 0 \text { otherwise. }\end{array}$ & 400 & 0.010 & 0.100 & 0 & 1 \\
\hline Household_members & Number of household members. & 400 & 4.355 & 1.266 & 1 & 11 \\
\hline
\end{tabular}

Source: Survey results. 


\section{References}

Bacolod, M. P., \& Ranjan, P. (2008). Why children work, attend school, or stay idle: the roles of ability and household wealth. Economic Development and Cultural Change, 56(4), 791-828. http://doi.org/10.1086/588165

Banco de México (2011). Informe anual. México D.F. Accessed August 2014: http://www.banxico.org.mx/ publicaciones-y-discursos/publicaciones/informes-periodicos/anual/\%7BF3075A61-2EF3-E85B-5A1CE8DE4BA3FB2C\%7D.pdf.

Baschieri, A., \& Falkingham, J. (2007). Staying in School: Assessing the Role of Access, Availability and Opportunity Cost. S3RI Application and Policy Working Paper no. A07/02. University of Southampton.

Basu, K., \& Van, P. H. (1998). The economics of child labour. The American Economic Review, 88(3), $412-427$.

Basu, K. (1999). Child labour: Cause, consequence, and cure, with remarks on international labour standards. Journal of Economic Literature, 37(3), 1083-1119. http://doi.org/10.7208/chicago/9780226041223.001.0001

Becker, G. S. (1964). Human capital: A theoretical and empirical analysis with special reference to education. New York: Columbia University Press.

Beegle, K., Dehejia, R., \& Gatti, R. (2005). Why Should We Care about Child Labour? The Education, Labour Market, and Health Consequences of Child Labour. World Bank Policy Research Working Paper no. 3479. Washington, DC: The World Bank.

Bhalotra, S. (2007). Is child work necessary? Oxford Bulletin of Economics and Statistics, 69(1), $29-55$. http://doi.org/10.1111/j.1468-0084.2006.00435.x

Botello Triana, J. (2011). Algunos indicadores del mercado del trabajo. Análisis Económico, XXVI(63), $247-263$.

Bracho, T. (1995). Gasto privado en educación. México, 1984-1992. Revista Mexicana de Sociología, 57(2), 91-119. http://doi.org/10.2307/3541071

Bray, M. (2007). The shadow education system: private tutoring and its implications for planners (2 edition). Paris: UNESCO, International Institute for Educational Planning.

Carrillo, M. (2006). La Teoría y la Promoción del Desarrollo Regional Sustentable. México: Benemérita Universidad Autónoma de Puebla.

Comisión Nacional Bancaria y de Valores [CNBV]. (2009). Primer Reporte de Inclusión Financiera. México, DF: CNBV.

Comisión Nacional Bancaria y de Valores [CNBV]. (2010). Segundo Reporte de Inclusión Financiera. México, DF: CNBV

Comisión Nacional para la Protección y Defensa de los Usuarios de Servicios Financieros [CONDUSEF] (2013). El sistema financiero informal. México D.F. Accessed: August 2013. http://www.condusef.gob.mx/index. php/instituciones-financieras/otros-sectores/casas-de-empeno/519-el-sistema-financiero-informal

De Hoyos, R., Martínez, J. M., \& Székely, M. (2010). Educación y movilidad social en México. Movilidad social en México. Población, desarrollo y crecimiento. México DF: Centro de Estudios Espinosa Yglesias.

Edmonds, E. V., \& Pavcnik, N. (2005). Child labour in the global economy. The Journal of Economic Perspective, 19(1), 199-220.

Ersado, L. (2005). Child labour and schooling decision in urban and rural areas: Comparative evidence from Nepal, Peru, and Zimbabwe. World Development, 33(3), 455-480.

Gunnarsson, V., Orazem, P. F., \& Sánchez, M. A. (2006). Child labour and school achievement in Latin America. The World Bank Economic Review, 20(1), 31-54.

Hochschild, J. L., \& Scovronick, N. B. (2004). The American dream and the public schools. Oxford University Press.

Instituto Nacional de Estadística y Geografía [INEGI] (2010). Encuesta Nacional de Ingresos y Gastos de los Hogares 2010. Microdatos. Accessed April 2013: http://www.inegi.org.mx/est/contenidos/proyectos/ accesomicrodatos/encuestas/hogares/regulares/enigh/2010tradicional/.

Instituto Nacional de Estadística Geografía [INEGI]. (2014). Banco de Información Económica. Encuesta mensual base 2008 de Manufactura, Comercio y Servicios. Aguascalientes.

Marcel, M., \& Tokman, C. (2005). ¿Cómo se financia la educación en Chile? Santiago de Chile: Gobierno de Chile, Ministerio de Hacienda.

Mincer, J. (1974). Schooling, experience and earnings. New York: Columbia University Press.

Morrisson, C. (2002). Health, Education and Poverty Reduction. Policy Brief no.19, OECD Development Centre. Paris: Organization for Economic Cooperation and Development.

OCDE/PISA (2000). Programa Internacional de Evaluación de los Alumnos de la OCDE. Accessed February 2013: http://www.oecd.org/pisa/keyfindings/.

OCDE/PISA (2003). Programa Internacional de Evaluación de los Alumnos de la OCDE. Accessed February 2013: http://www.oecd.org/pisa/keyfindings/. 
OCDE/PISA (2006). Programa Internacional de Evaluación de los Alumnos de la OCDE. Accessed February 2013: http://www.oecd.org/pisa/keyfindings/.

OCDE/PISA (2009). Programa Internacional de Evaluación de los Alumnos de la OCDE. Accessed Febraury 2013: http://www.oecd.org/pisa/keyfindings/.

OECD and UNESCO (2002). Financing Education: Investments and Returns: Analysis of the World Education Indicators 2002. Paris: OECD Publishing \& UNESCO Publishing.

Orazem, P., \& Gunnarsson, V. (2003). Child Labour, School Attendance, and Performance: A Review. Working paper, International Labour Office \& International Programme on the Elimination of Child Labour, Geneva.

Pavón, L. (2010). Financiamiento a las microempresas y las pymes en México (2000-2009). Serie financiamiento del desarrollo no. 226. Santiago de Chile: CEPAL-Naciones Unidas.

PROMÉXICO. (2014). Selección de indicadores de inversión y comercio. Accessed April 2015: http://mim.promexico.gob.mx/wb/mim/seleccion_de_indicadores.

Raccanello, K. (2012). Salud, educación y nutrición: una revisión de la literatura en el marco de los Objetivo de Desarrollo del Milenio. In P. Nelida Asili (Ed.), Vida Sustentable (pp. 364-390). UDLAP.

Raccanello, K., \& Saucedo Carranza, C. B. (2015). Microempresas y microcréditos en la ciudad de Puebla. Perspectivas: Revista de Análisis de Economía, Comercio y Negocios Internacionales, 9(1), 5-27.

Rosati, F. C., \& Rossi, M. (2007). Impact of school quality on child labour and school attendance: The Case of CONAFE Compensatory Education Program in Mexico. Understanding Children's Work (UCW) Project.

Rumberger, R. W. (1995). Dropping out of middle school: A multilevel analysis of students and schools. American Educational Research Journal, 32(3), 583-625. http://doi.org/10.3102/00028312032003583

Santibáñez, L., Campos, M., \& Jarillo, B. (2011). 10 puntos para entender el gasto educativo en México: Consideraciones sobre su eficiencia. México Evalúa. Accessed March 2013: http://www.mexicoevalua.org/wp-content/ uploads/2013/02/MEX_EVA-INHOUS-GASTO_EDU-LOW.pdf.

Secretaría de Educación Pública [SEP] (2010). Sistema de Indicadores Educativos (INDISEP). México D.F.

Secretaría de Educación Pública [SEP] (2011). Sistema de Indicadores Educativos (INDISEP). México D.F.

Secretaría de Educación Pública [SEP] (2012). Principales cifras e indicadores educativos para el ciclo escolar 2011 -2012. México D.F.

Secretaría de Economía [SE] (2010). Microempresas. México, D.F.: Secretaría de Economía.

Secretaría de Hacienda y Crédito Público [SHCP], Comisión Nacional Bancaria y de Valores [CNBV] \& Instituto Nacional de Estadística y Geografía [INEGI] (2012). Encuesta Nacional de Inclusión Financiera 2012 [ENIF]. México D.F.

Serrano, L. (1996). Indicadores de Capital Humano y Productividad. Revista de Economía Aplicada, IV(10), $177-190$.

UNESCO. (2010a). World Data on Education. VII Ed. 2010/11. UIS Statistics in Brief. Accessed February 2013: http://stats.uis.unesco.org/unesco/TableViewer/document.aspx?ReportId=121\&IF_Language=eng\&BR_Country $=4840$.

UNESCO. (2010b). Informe de Seguimiento de la Educación para Todos en el Mundo. Accessed February 2013: http://www.unesco.org/new/es/education/themes/leading-the-international-agenda/efareport/.

UNESCO. (2011). Informe de Seguimiento de la Educación para Todos en el Mundo. Accessed February 2013: http://www.unesco.org/new/es/education/themes/leading-the-international-agenda/efareport/.

Yuren, T., de la Cruz, M., Cruz, A., Araújo-Olivera, S. S., \& Estrada, M. J. (2005). Mundo de la Vida versus habitus Escolar: El Caldo de Cultivo del Rezago Educativo en un México de Migrantes. Archivos Analíticos de Políticas Educativas, 13(13). Accessed June 2010: http://epaa.asu.edu/epaa/v13n13/. 